carbonize approximately six and a half million tons of coal per year. This figure is equivalent to one third of the total carbonizing capacity of the industry. Naturally this prodigious increase in the number and capacity of plants provided by steelworks has deprived colliery-owned coke ovens of a large proportion of the market for furnace coke. Nevertheless, there is no cessation of coking at the collieries, as is apparent from the fact that, during the period 1934-37, 664 coke ovens were ordered by British collieries. So far as future developments of the industry are concerned, much depends upon the attitude adopted by coal owners and on the education of popular opinion towards a correct understanding of the principles involved. Carbonized fuel, whether solid or gaseous, is eminently suitable for domestic heating. The coal trade must be brought to realize this and steps should be taken to compensate for the inevitable loss of revenue which will follow the disappearance of raw coal from the domestic fuel market. Instead of fighting to retain raw coal in this market by raising the price of coal to those who make smokeless fuel, the coal trade should develop a widespread scheme of collaboration with producers of carbonized fuel. By-product coking is as fundamentally im. portant an industry to the nation as a whole as is the coal industry, and as such it should be developed both technically and commercially with the greatest possible foresight.

\section{A Bridge Without Bolts or Rivets}

IT is stated in Electric Welding of February, a bi-monthly magazine published by the Quasi-Arc Co., Ltd., of London, that the London Passenger Trans. port Board has placed the contract for the building of a new bridge to carry the Hammersmith and City Railway over Ladbroke Grove, just outside Ladbroke Grove Station. The new bridge is to be of all-welded construction, and will be the first of its type and size in Great Britain. The present bridge has been in service for seventy years. The advantages of having a bridge without bolts and rivets are : the reduction of weight by one fifth, a substantial reduction of cost and much less noise during construction. The new bridge will be $60 \mathrm{ft}$. long; it will be built on three girders instead of two, and there will be a ballasted track instead of a timber track. These improvements will give much quieter running and also more steadiness and strength. It will be erected on trestles beside the present bridge, and early one Sunday morning the old structure will be rolled away and the new one rolled into place. Dr. Schaper, chief engineer of the German State Railways, stated in a paper last May read before a joint meeting of the Institution of Civil Engineers and the Institution of Structural Engineers that already at that time there were 150 all-welded railway bridges in service on the Reichsbahn up to spans of $177 \cdot 2 \mathrm{ft}$. At least as many all-welded bridges have been constructed in connexion with the new German arterial motor roads with spans nearly $100 \mathrm{ft}$. long. In Belgium nearly fifty welded bridges of the Vierendeel type up to spans of $295 \mathrm{ft}$. have been constructed over the Albert Canal. It seems certain that, in the future, welding will play an increasingly large part in the technique of construction.

\section{Safeguarding London's Water Supply}

MuCH information of considerable interest to the biologist and hygienist, chemist and bacteriologist is included in the thirty-first annual report of the Metropolitan Water Board, which contains the results of the chemical and bacteriological examinations of London waters during 1936, compiled by the Director of Water Examination, Lieut.-Colonel Harold (London: P. S. King and Son, Ltd. 10s. 6d.). The daily supply of water in 1936 averaged $287 \cdot 7$ million gallons, yielding 96.5 per cent of samples regarded as being of first-class quality. In the laboratories, 35,075 samples were examined in order to keep a watch upon the purity of the supply. In the Bacteriological Section investigations were conducted on the routine methods for the isolation and identification of Bacillus coli and allied bacteria, and on the isolation of $B$. paratyphosus B and of streptococci. Turbidity estimations, and the action on metals of tap-water before and after softening, have been investigated in the Chemical Section. Much trouble is sometimes caused in the reservoirs by the growth of Algæ, and the relation of chemical composition of the water to problems of algal production is one of the subjects investigated in the Biological Section. An interesting find was the blind well shrimp, Niphargus aquilex, which is naturally a subterranean species, but which has established itself in the filter beds at the Kempton Park Works. The report concludes with the tables containing the chief analytical results obtained.

\section{Transport of Tropical Fruits and Vegetables}

THE Imperial College of Tropical Agriculture, Trinidad, publishes, as Memoir No. 7, November 1937, a very valuable summary of the methods now avail. able to bring the produce of the tropics to the English markets, which goes far to explain the greater variety and interest of the window display of the greengrocer and the fruiterer throughout all the months of the year. Some 150 names of vegetables and fruits are listed-for many of these, as citrons, bananas and pineapples there is already much experience gathered and a long bibliography to cite, while others like mangoes and the papaw attract attention as household words of the tropics from which much is to be hoped if distance and time can be conquered; but so far their tramsport is evidently in the experimental stage. Many of the fruits and vegetables enumerated have been but names, if that, to dwellers in the temperate zones so far ; the litchi has arrived in much larger quantities lately and been much appreciated; the mangosteen and the langsat are still awaited. This list raises many hopes, and this concise summary of practical experience should prove of material value in enabling importers and trans. porters to learn how much has already been achieved and what possibilities there are for the future. Copies of this publication may be obtained (price 48 ., British; 4s. 6d., foreign) on application to the Editor, Tropical Agriculture, Imperial College of Tropical Agriculture, Trinidad, B.W.I. 